\title{
溶銑への $\mathrm{Al}$ 添加による石灰吹き込み脱硫反応の促進 論 文
}

\author{
庄司 武志* 満尾 利晴*2

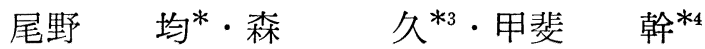

\section{Improvement of Desulfurization by Aluminum Addition into Hot Metal in Powdered Lime Injection Process}

\author{
Takeshi ShojI, Toshiharu Mitsuo, Yoshihiro HAtтA, \\ Hitoshi ONO, Hisashi MORI, and Tsuyoshi KAI
}

\begin{abstract}
Synopsis :
Improvement was obtained for the reaction efficiency of hot metal desulfurization by lime powder injection with $\mathrm{N}_{2}$ gas by prior addition of aluminum. That is, the desulfurization rate was markedly faster for $\mathrm{Fe}-\mathrm{C}_{\mathrm{sat}}-\mathrm{Si}-\mathrm{Al}-\mathrm{S}$ melt than for $\mathrm{Fe}-\mathrm{C}_{\mathrm{sat}}-\mathrm{Si}-\mathrm{S}$ melt. Reaction layers on a lime lump immersed in the melts were examined by use of electron probe microanalysis and X-ray diffraction. The improvement of reaction efficiency of lime by aluminum addition was interpreted by the following results of the investigation.

In $\mathrm{Fe}-\mathrm{C}_{\mathrm{sat}}-\mathrm{Si}-\mathrm{S}$ melt, solid $2 \mathrm{CaO} \cdot \mathrm{SiO}_{2}$ and $3 \mathrm{CaO} \cdot \mathrm{SiO}_{2}$ layer were formed on the lime surface, which retarded sulfur transfer to its interior. On the contrary, for $\mathrm{Fe}-\mathrm{C}_{\mathrm{sat}}-\mathrm{Si}-\mathrm{Al}-\mathrm{S}$ melt, molten $\mathrm{CaO}-\mathrm{Al}_{2} \mathrm{O}_{3}-\mathrm{FeO}$ layer was formed on the lime surface, which enhanced sulfur transfer, and moreover the layer disolved sulfur up to appoximately $50 \%$.

Aluminum concentration to get the improvement of reaction efficiency of lime for plant scale operation in $250^{\mathrm{t}}$ torpedo ladle was determined to be $0.005+\Delta \mathrm{Al} \%$, where $\Delta \mathrm{Al}$ is the amount of aluminum loss during the desulfurization.
\end{abstract}

\section{1. 緒言}

近年，省エネルギー方策の一環として，分塊圧延後の 鋼片を再加熱することなく熱間圧延するいわゆる直送圧 延の普及にともない，鋼片の無欠陥化が不可欠となり種 々の対策が講じられているが，とりわけ低硫化が有効な 手段であることから，大量の溶銑を安洒に脱硫する方法 の開発が重要な課題となつた。

従来より溶銑の脱硫剤として使用されてきた高価な カルシウムカーバイド $\left(\mathrm{CaC}_{2}\right)$ にかえて安価な生石死 $(\mathrm{CaO})$ を使用する埸命，熱力学的な脱硫限界は 0.001 \%以下であるが父心速度が避いため ${ }^{122)}$ ，脱硫剤の吹き 込及時間の延長による処理能力の低下，耐火物寿命の低 ドな゙種々の問題を招くので， $\mathrm{CaO}$ を脱硫剤として採 用するためには反交速度の问上が必要である.

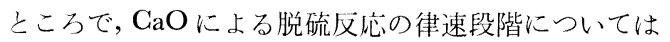
種々の研究が行われているが, 著者らは石灰表面での反
応生成物層の生成挙動が脱硫速度を決定すると考え, 溶 銑中にあらかじめ $\mathrm{Al}$ を添加したのち $\mathrm{CaO}$ 粉末をイン ジェクションする方法を研究した. すなわち $\mathrm{Fe}_{\text {到 }} \mathrm{sat}^{-}$ $\mathrm{S}$ 系溶鉄の $\mathrm{CaO}$ による脱硫反応は一般に(1)および (2) 式で表されるが，溶鉄中に $\mathrm{Si}$ を含む場合には(3)

$$
\begin{aligned}
& \mathrm{CaO}+\mathrm{S}=\mathrm{CaS}+\mathrm{O} \cdots \cdots \cdots \cdots \cdots \cdots \cdots \cdots \cdots \cdots(1) \\
& \mathrm{O}+\mathrm{C}=\mathrm{CO} \\
& 2 \mathrm{O}+\mathrm{Si}=\mathrm{SiO}_{2}
\end{aligned}
$$

式の反応がおこる．溶鉄中の $\mathrm{Si}$ はS の活量を増大させ るので促来から脱硫に有効であると考えられてきたが， 川合ら ${ }^{3)}$ は $\mathrm{Si}$ の存在が逆に脱硫速度を低下させると報 告しており，このことは $\mathrm{CaO}$ の表面に脱硫反応を阻害 するカルシウムシリケート層が生成するためと考えられ る.さらに， $\mathrm{CaO}$ に $\mathrm{Al}$ を添加して吹き込むことによ り，溶銑の脱硫が向上するとの報告4) もある.そこで溶 銑に $\mathrm{Al}$ を添加することにより， $\mathrm{CaO}$ と $\mathrm{S}$ の反応によ

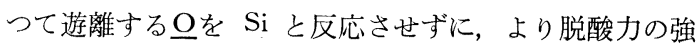

眧和 55 作 4 月本会篟演大会にて発表 昭和 55 年 12 月 26 日受付 (Received Dec. 26, 1980)

* 新日本製鉄 (株) 堺製鉄所 (Sakai Works, Nippon Steel Corp., 1 Chikkoyawata-cho Sakai 590)

*2 新H本製鉄 (株) 製品技術研究所 工博 (Products R \& D Laboratories, Nippon Steel Corp.)

*3 新月本製鉄(株)堺製鉄所 埋博 (Sakai Works, Nippon Steel Corp.)

*4 新日本製鉄 (株) 堺製鉄所 (現：日新製鋼 (株) (Sakai Works, Nippon Steel Corp., Now Nisshin Steel Co., Ltd.) 
い $\mathrm{Al}$ と反応させて低融点のカルシウムアルミネート層 を生成させようと考光た．以下に $\mathrm{Al}$ 添加に上る脱硫反 応促進機構と実操業への適用結果について述べる.

\section{2. 溶銑への $\mathrm{Al}$ 添加による $\mathbf{G a O}$ の脱硫反 応促進機構}

\section{$2 \cdot 1$ 実験方法}

$2 \cdot 1 \cdot 1$ 脱硫剤吹き达及実験

$\mathrm{MgO}$ で内径 $300 \mathrm{~mm} \phi$ にスタンプした $300 \mathrm{~kg}$ 高周 波誘導溶解炉を用いて銑鉄 $200 \mathrm{~kg}$ (浴深 $430 \mathrm{~mm}$ ) を溶 解し, $\mathrm{Fe}-\mathrm{C}_{\text {sat. }}-\mathrm{S}$ 系 $(\mathrm{S}=0.040), \mathrm{Fe}-\mathrm{C}_{\text {sat. }}-\mathrm{Si}-\mathrm{S}$ 系 ( $\mathrm{Si}$ $\fallingdotseq 0.60 \% \mathrm{Mn}=0.60 \%, \mathrm{~S}=0.040 \%), \mathrm{Fe}-\mathrm{C}_{\mathrm{sat}} . \mathrm{Si}-\mathrm{Al}-\mathrm{S}$ 系 $(\mathrm{Si}=0.60 \%, \mathrm{Mn} \fallingdotseq 0.60 \%, \mathrm{~S} \fallingdotseq 0.040 \%, \mathrm{Al}=0.1 \%$ 添加）に成分調整した．脱硫剤は $20 \sim 60$ メッシュに粒 度調整したのち内径 $8 \mathrm{~mm} \phi$ の黒鉛製ランスを用いて, 浴深 $100 \mathrm{~mm}$ の位置に $\mathrm{N}_{2}$ ガスで吹き込んだ. 脱硫剤 の吹き込みは初期 3 min で完了した。実験中, 溶銑温度 を $1400^{\circ} \mathrm{C}$ 亿保持し，浴面には混銑車上吹き脱硫法の実 操業状態をシミュレートする意味で混銑車スラグ $(\mathrm{CaO}$ $39.1 \%, \mathrm{SiO}_{2} 37.3 \%, \mathrm{Al}_{2} \mathrm{O}_{3} 9.7 \%, \mathrm{FeO} 3.8 \%, \mathrm{MnO}$ $2.2 \%$ ， S $1.66 \%$ ） $1.5 \mathrm{~kg}$ 浮かせて実験した.

\section{$2 \cdot 1 \cdot 2$ 脱硫剂浸漬実験}

$15 \mathrm{~kg}$ 高周波誘導溶解炉に七ットした黒鉛るつぼ（70 $\mathrm{mm} \phi \times 90 \mathrm{mmh})$ 内で鉄鉄 $(\mathrm{C} 4.3 \%$, Si $0.40 \%, \mathrm{Mn}$ $0.60 \%, \mathrm{~S} 0.003 \%$ および $0.040 \%, \mathrm{Al}$ 添加の有無） 2 $\mathrm{kg}$ を溶解し， $1400^{\circ} \mathrm{C}$ で実験した。試料はFig. 1 に 示す黒鉛製ホールダーに入れてホールダーごと溶銑中に 1 60 min 浸漬して反応させた. 浸漬後の試料は $1 / 2$ 断 面を ト研磨を行いEPMA 用試料とした。 また反応層を削り 取つてX線回折用に供した.

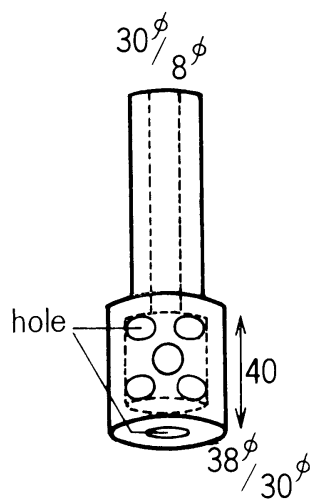

Fig. 1. Sample holder made of carbon.

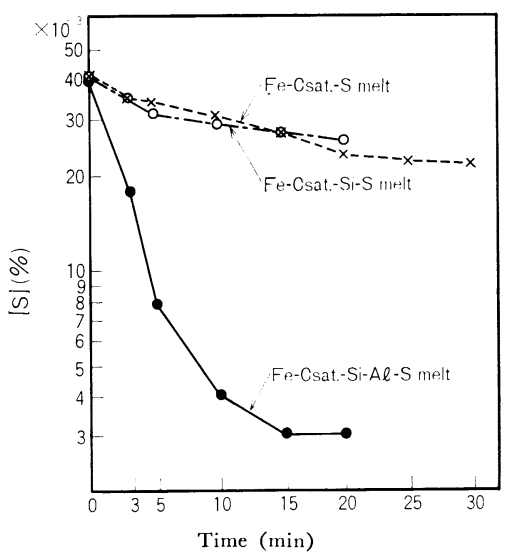

Fig. 2. Increase of desulfurization rate for powdered lime injection by prior addition of $\mathrm{Al}$ to hot metal.

\section{$2 \cdot 2$ 実験結果}

$2 \cdot 2 \cdot 1 \mathrm{CaO}$ 吹き込及実験

ロータリーキルンで焼成し， 20〜60メッシュに粒度 調整した $\mathrm{CaO}$ を $12 \mathrm{~kg} / \mathrm{t}$ の割合で吹き込んだ結果を Fig. 2 に示す. Fe-C sat. $^{-}$Si-S 系の溶銑を脱硫する場 合に比較して, $\mathrm{Fe}-\mathrm{C}_{\mathrm{sat}} .-\mathrm{Si}-\mathrm{Al}-\mathrm{S}$ 系溶銑の場合には脱 硫速度が大幅に向上した。 $\mathrm{CaO}$ で脱硫する場合の溶銑

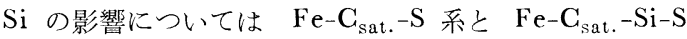
系で差が認められなかつた。

\section{$2 \cdot 2 \cdot 2 \mathrm{CaO}$ 塊浸漬実験}

$\mathrm{CaO}$ はロータリーキルンにより $1250^{\circ} \mathrm{G} て ゙$ 焼成した もの，および炭酸カルシウム試薬(特級)を焼成したのち $10 \mathrm{~mm} \phi \times 10 \mathrm{mmh}$ にプレス成型（成型圧力 $2 \mathrm{t}$ ） し, 高 周波誘導炉（発熱体……黑鉛）により $1840^{\circ} \mathrm{C}$ で3 h 焼 成したものを用いた。 浸漬後の $\mathrm{CaO}$ 試料の断面の $\mathrm{E}$ PMA に上る $\mathrm{K}_{\alpha}$ 線像を Photo. 1 亿示す。溶銑中に $\mathrm{S}$ を $0.003 \%$ しか含まない $\mathrm{Fe}-\mathrm{C}_{\text {sat. }}-\mathrm{Si}$ 系では反応層の 生成が認められなかつた。一方 $\mathrm{S}$ 0.040\% 含を系で は反応層の生成が認められ，Al 含有の有無によつて反 応層内の元素分布およびその濃度が異なり，またFig. 3 に示すように反応層の成長速度も $\mathrm{Al}$ の添加によつて数 倍に増大することがわかる．Fig. 4 に反応層の EPMA による定量分析の結果を示す. $\mathrm{Fe}-\mathrm{C}_{\mathrm{sat}} .-\mathrm{Si}-\mathrm{S}$ 系では $\mathrm{Si}$ が $12 \%, \mathrm{~S}$ が $5 \%$ 以下であるのに対して， $\mathrm{Fe}_{-}-\mathrm{C}_{\mathrm{sat}}{ }^{-}$

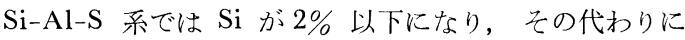
$\mathrm{Al}$ が 10〜 15\%, Fe が 10〜 15\% になるとともに S の 濃度が 10〜40\%にも達することが確認された。 また Photo. 1(c) に示すように， ロータリーキルン焼成石 灰を浸漬した場合は Fe の浸透は気孔やクラックなど 空隙部を通じて深く入つているが，Photo. 1(d)に示与 


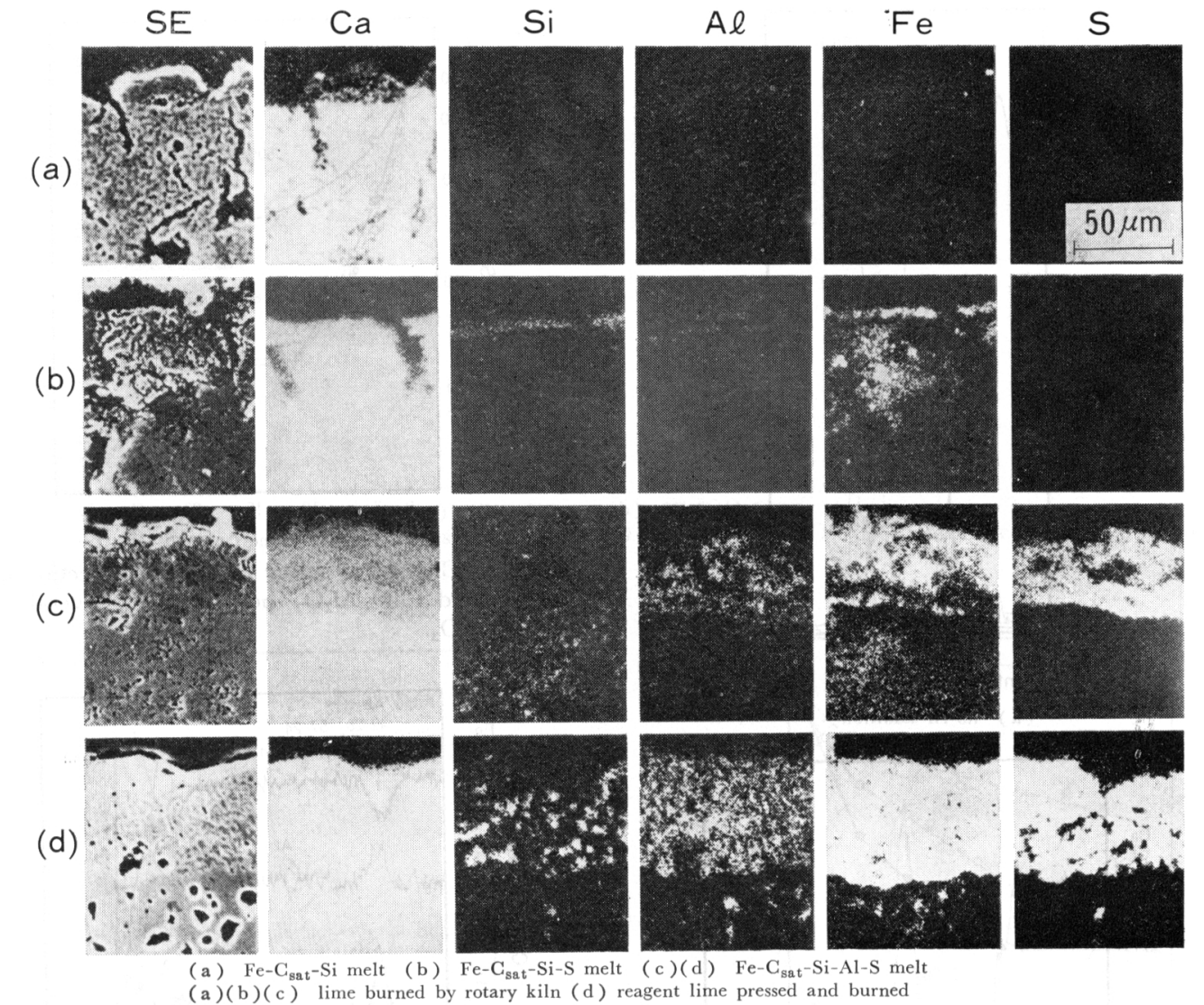

Photo. 1. Electron scanning images of reaction layers on lump limes immersed into hot metal for 5 minutes.

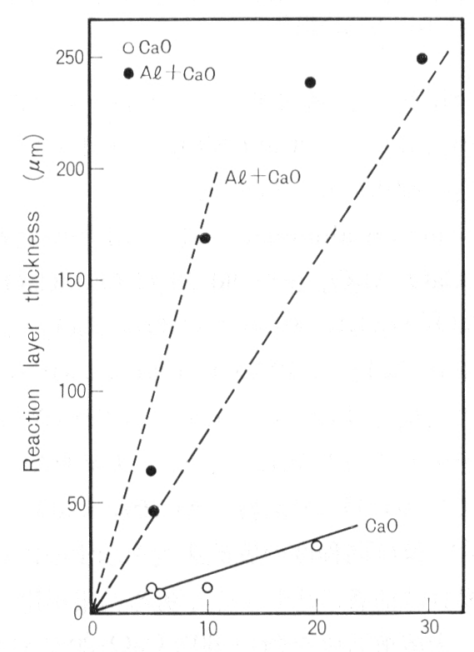

Immersion time ( $\mathrm{min}$ )

Fig. 3. Growth rate of reaction layer on the surface of immersed lump lime.
Table 1. Determination of compounds in the reaction layer of lump lime.

\begin{tabular}{cccc}
\hline Melt & Immersion time & Method & Identified compounds \\
\hline Fe- $\mathrm{C}_{\mathrm{sat}}-\mathrm{Si}-\mathrm{S}$ & 60 (min) & EPMA & $\begin{array}{l}2 \mathrm{CaO} \cdot \mathrm{SiO}_{2}, \\
3 \mathrm{CaO} \cdot \mathrm{SiO}_{2}\end{array}$ \\
\hline Fe- $\mathrm{C}_{\text {sat }}$-Si-Al-S & 60 & $\begin{array}{c}\mathrm{X}-\mathrm{ray} \\
\text { diffraction }\end{array}$ & $\begin{array}{l}\mathrm{CaS}, \mathrm{CaO}, 2 \mathrm{CaO}-\mathrm{SiO}_{2} \\
12 \mathrm{CaO} \cdot 7 \mathrm{Al}_{2} \mathrm{O}_{3}, 2 \mathrm{CaO} \cdot \\
\mathrm{Fe}_{2} \mathrm{O}_{3}, 4 \mathrm{CaO} \cdot \mathrm{Fe}_{2} \mathrm{O}_{3} . \\
\mathrm{Al}_{2} \mathrm{O}_{3}\end{array}$ \\
\hline
\end{tabular}

プレス成型後焼成した石灰の場合には, 反応層の境界は 明瞭で Fe のみ先行して浸透する現象はみられなかつ た。 また， Table 1 に反応生成物の同定結果を示すが, Al 無添加の場合の生成物は Calcium silicate であるの に対して, $\mathrm{Al}$ 添加の場合には $\mathrm{CaS}, 12 \mathrm{CaO} \cdot 7 \mathrm{Al}_{2} \mathrm{O}_{3}$, $2 \mathrm{CaO} \cdot \mathrm{Fe}_{2} \mathrm{O}_{3}, 4 \mathrm{CaO} \cdot \mathrm{Al}_{2} \mathrm{O}_{3} \cdot \mathrm{Fe}_{2} \mathrm{O}_{3}, 2 \mathrm{CaO} \cdot \mathrm{SiO}_{2}$ などが 認められた。

2.2.3 Calium aluminate, calcium silicate による 脱硫実験

Calcium aluminate として $3 \mathrm{CaO} \cdot \mathrm{Al}_{2} \mathrm{O}_{3}$ を，また溶 銑に $\mathrm{Al}$ を添加しない場合の反応生成物である $2 \mathrm{CaO}$. 


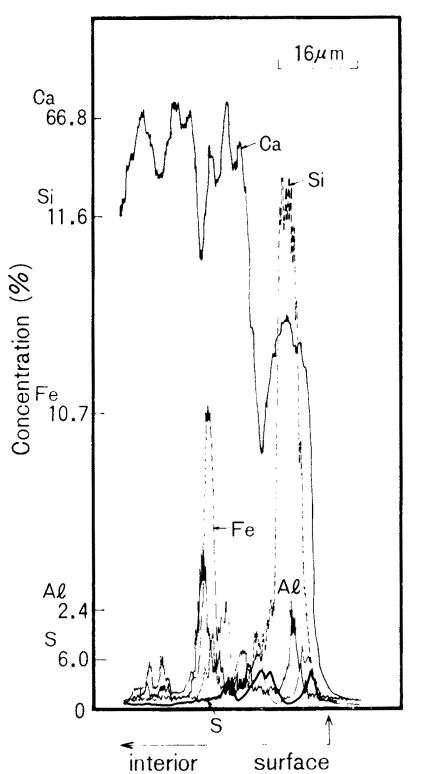

(a) no Al addition

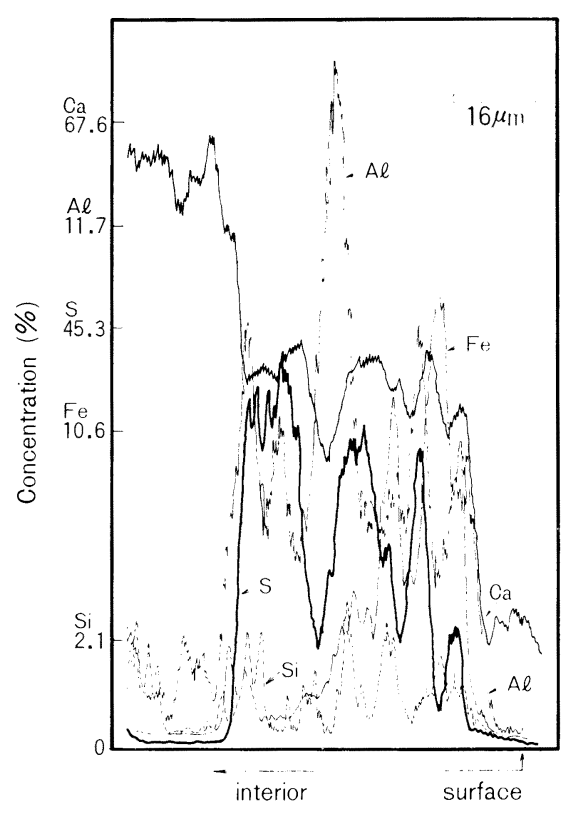

(b) Al addition

Fig. 4. Electron probe microanalysis on the cross section of lump limes immersed into hot metal for 5 minutes.

$\mathrm{SiO}_{2}$ を選び浸漬実験を行つた。実験に際して塊状の $2 \mathrm{CaO} \cdot \mathrm{SiO}_{2}$ を製作するために $\mathrm{P}_{2} \mathrm{O}_{5}$ (試薬) $2.5 \%$ を添 加し，レーザーにより溶解した。また $3 \mathrm{CaO} \cdot \mathrm{Al}_{2} \mathrm{O}_{3}$ は $\mathrm{CaO}$ と $\mathrm{Al}_{2} \mathrm{O}_{3}$ の試薬を混合し, $1800^{\circ} \mathrm{C}$ 以上で溶解し た. 浸漬実験の結果を Photo. 2 亿示す. $3 \mathrm{CaO} \cdot \mathrm{Al}_{2} \mathrm{O}_{3}$

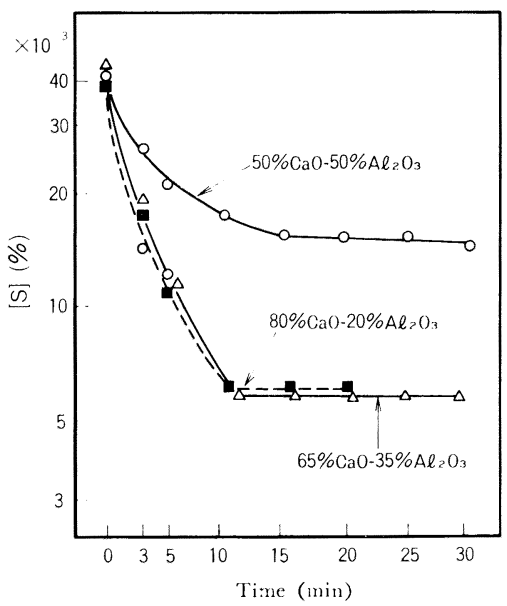

Fig. 5. Change of sulfur content by injection of pre-melted $\mathrm{CaO}-\mathrm{Al}_{2} \mathrm{O}_{3}$ powders with several of $\mathrm{CaO} / \mathrm{Al}_{2} \mathrm{O}_{3}$.

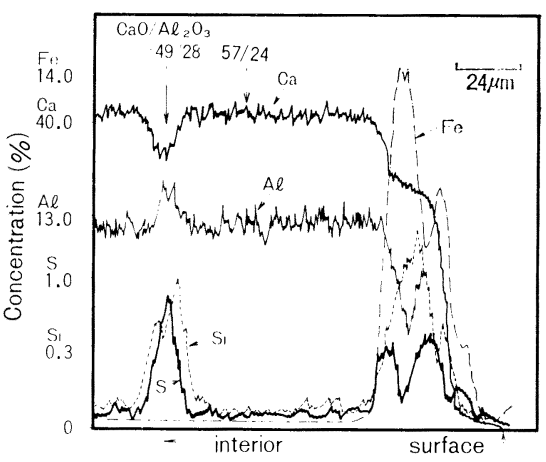

Fig. 6. Electron probe microanalysis on the cross section of lump $65 \% \mathrm{CaO}-35 \% \mathrm{Al}_{2} \mathrm{O}_{3}$ immersed into hot metal for 5 minutes.

では $\mathrm{Fe}, \mathrm{Si}, \mathrm{S}$ の浸透層が厚く, 脱硫反心の進行が認 められるのに対して，2 $\mathrm{CaO} \cdot \mathrm{SiO}_{2}$ では $\mathrm{Fe}$ と若下の $\mathrm{Al}$ 以外の浸透は認められなからた。

ついで calcium aluminate 組成の影淛を調査した. すなわち $\mathrm{CaO} / \mathrm{Al}_{2} \mathrm{O}_{3}$ 比を $80 / 20\left(\mathrm{CaO}+3 \mathrm{CaO} \cdot \mathrm{Al}_{2} \mathrm{O}_{3}\right)$ $65 / 35\left(3 \mathrm{CaO} \cdot \mathrm{Al}_{2} \mathrm{O}_{3}\right), 50 / 50\left(12 \mathrm{CaO} \cdot 7 \mathrm{Al}_{2} \mathrm{O}_{3}\right)$ に変化さ せ，それぞれ $12 \mathrm{~kg} / \mathrm{t}, 10 \mathrm{~kg} / \mathrm{t}, 12 \mathrm{~kg} / \mathrm{t}$ の吹き込及を行 つたそその結果を Fig. 5 亿示す。、ずれの組成比のも のも脱硫能があることを示したが， $\mathrm{CaO} / \mathrm{Al}_{2} \mathrm{O}_{3}$ 比が $80 / 20$ および 65/35 の場合に $\mathrm{Al}$ 添加 $\mathrm{CaO}$ 吹き込及 脱硫の場合とほぼ同程度の脱硫速度を示すのに対して, 50/50 の場合は前者に比してやや劣る結果が得られた.

つぎに，未溶解石灰を含も $80 \% \mathrm{CaO} \cdot 20 \% \mathrm{Al}_{2} \mathrm{O}_{3}$ 塊の 浸漬実験の結果を Photo. 3 に示すが，まず Fe の移動 がマトリックスである calcium aluminate 領域で行わ 
(a)
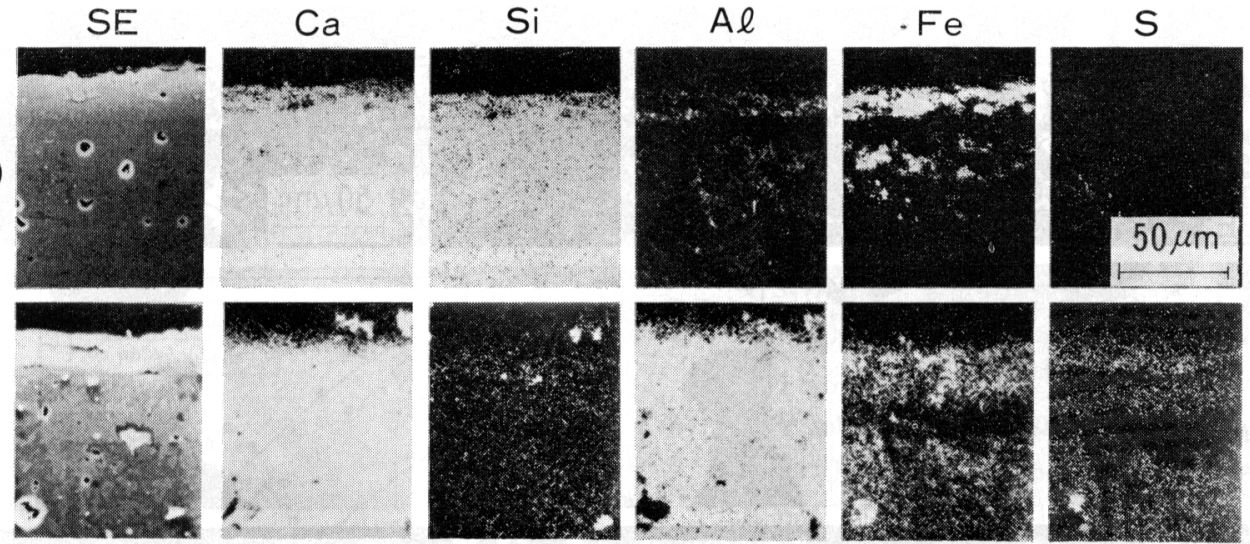

$\begin{array}{lll}\text { (a) } 2 \mathrm{CaO} \cdot \mathrm{SiO}_{2} & \text { (b) } 3 \mathrm{CaO} \cdot \mathrm{Al}_{2} \mathrm{O}_{3}\end{array}$

Photo. 2. Electron scanning images of lump $2 \mathrm{CaO} \cdot \mathrm{SiO}_{2}$ and $3 \mathrm{CaO} \cdot \mathrm{Al}_{2} \mathrm{O}_{3}$ immersed into hot metal for 5 minutes.

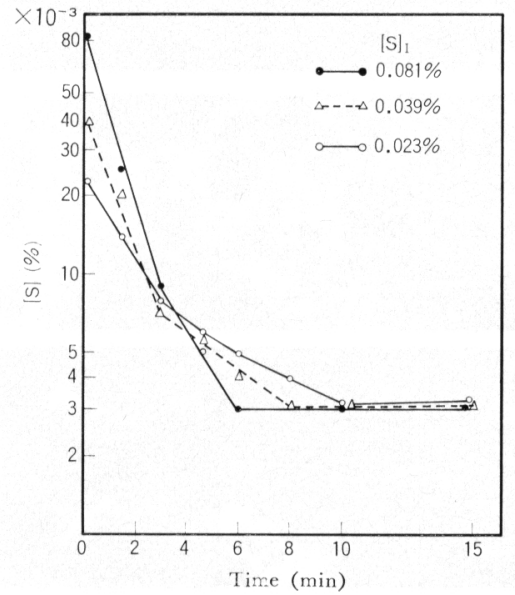

Fig. 7. Influence of initial sulfur concentration on desulfurization rate of hot metal containing $\mathrm{Al}$ by $\mathrm{CaO}$.

れ，その後 $\mathrm{CaO}$ の粒子が消失し，高濃度の $\mathrm{S}$ が検出さ れる現象が認められた.

また $65 \% \mathrm{CaO} \cdot 35 \% \mathrm{Al}_{2} \mathrm{O}_{3}$ の浸漬実験結果を詳細に観 察すると Fig. 6 亿示すように $\mathrm{CaO} / \mathrm{Al}_{2} \mathrm{O}_{3}$ 比が $57 / 24$ の部分に S が濃化せず, $49 / 28$ 部に濃化するといら現象 が認められた。

\section{$2 \cdot 2 \cdot 4$ 脱硫速度に求よぼす実験条件の影響}

（1）初期硫黄濃度の影響

初期硫黄濃度 $[\mathrm{S}]_{\mathrm{I}}$ を变觉て（他の実験条件は 2・1・1 に同じ）吹き込み実験を行いFig. 7 に示す結果を得 た. $[\mathrm{S}]_{\mathrm{I}}$ の変化により反応速度定数 $K$ の值が異なるこ とがわかつた。

（2）溶銑温度の影響

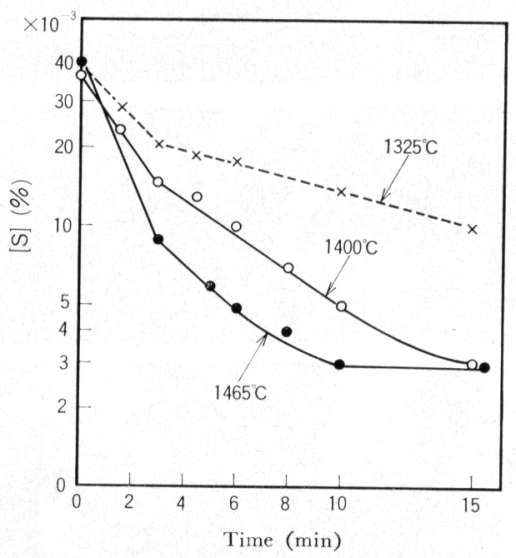

Fig. 8. Influence of hot metal temperature on desulfurizauion rate.

溶銑温度を変觉て吹き込み実験を行い, 反応速度にお よぼす溶銑温度の影響を調査した. その結果を Fig. 8 に示すが，溶銑温度が高いほど脱硫速度が大きかつた。 さらに $\mathrm{CaO}$ の $1250^{\circ} \mathrm{C}$ 溶銑への浸漬実験（他の実験 条件は $2 \cdot 1 \cdot 2$ に同じ) の結果を Photo. 4 に示すが脱 硫反応は極めてわずかしか起こらなかつた。

\section{3. 実操業への適用試験}

\section{$3 \cdot 1$ 実験方法}

混銑車上吹き脱硫装置を用い, Table 2 に示す操業諸 元によつて実操業試験を行つた， $\mathrm{Al}$ は $\mathrm{CaO}$ 吹き达み に先行して溶銑中に添加し溶解した.

\section{$3 \cdot 2$ 実験結果}

\section{$3 \cdot 2 \cdot 1 \mathrm{CaO}$ 吹き込又実験}

Al 添加の有無による脱硫率の 比較を Fig. 9 に示 

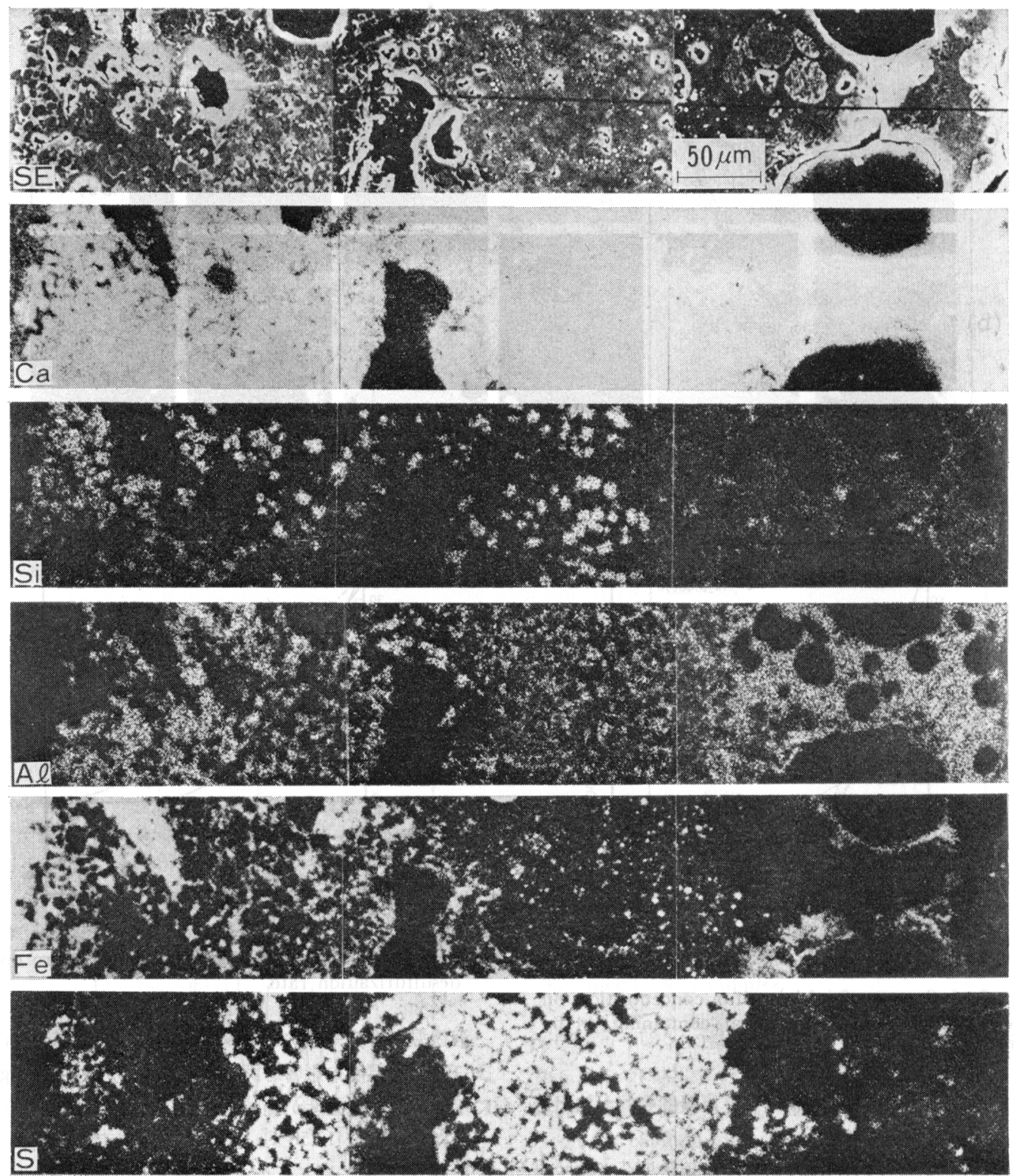

surface

interior

Photo. 3. Electron scanning images of lump $80 \% \mathrm{CaO}-20 \% \mathrm{Al}_{2} \mathrm{O}_{3}$ immersed into hot metal for 10 minutes.
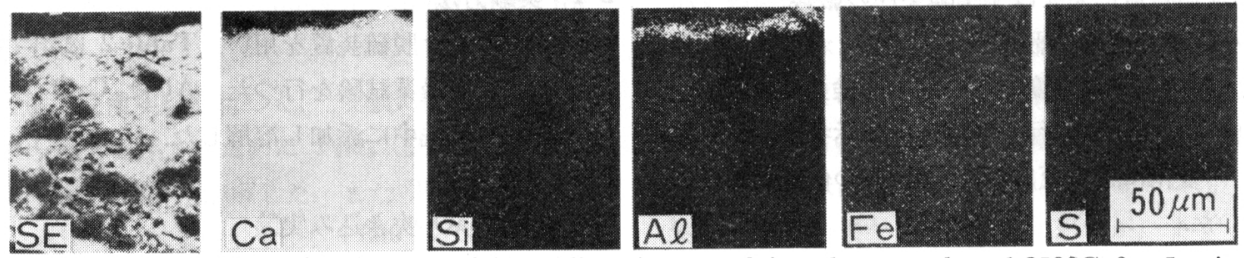

Photo. 4. Electron scanning images of lump lime immersed into hot metal at $1250^{\circ} \mathrm{C}$ for 5 minutes. 
Table 2. Operational variables of hot metal desulfurization by powdered lime injection into 250 t torpedo ladle.

\begin{tabular}{|c|c|c|c|c|c|c|}
\hline $\mathrm{Al}$ & Hot metal & Initial $[\mathrm{S}]$ & $\mathrm{N}_{2}$ flow rate & $\begin{array}{l}\text { Immersion dep- } \\
\text { th of lance }\end{array}$ & $\begin{array}{l}\text { Lime injection } \\
\text { rate }\end{array}$ & $\begin{array}{l}\text { Lime consu- } \\
\text { mption }\end{array}$ \\
\hline $\begin{array}{l}\text { No addition } \\
\text { Addition }\end{array}$ & $220^{\mathrm{t} / \mathrm{ch}}$ & $0.03 \sim 0.04$ & $\underset{300 \sim 500}{\mathrm{Nm}^{3} / \mathrm{h}}$ & $1.5 \sim 1.8^{\mathrm{m}}$ & $\begin{array}{l}\mathrm{kg} / \mathrm{min} \\
50 \sim 60\end{array}$ & $\begin{array}{l}3 \sim 7 \mathrm{~kg} / \mathrm{t} \\
2 \sim 6\end{array}$ \\
\hline
\end{tabular}

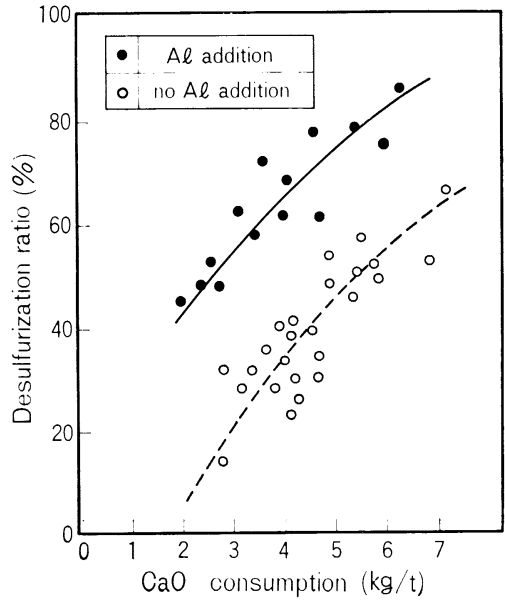

Fig. 9. Effect of $\mathrm{Al}$ addition into hot metal on desulfurization ratio by powdered lime injection into $250 \mathrm{t}$ torpedo ladle.

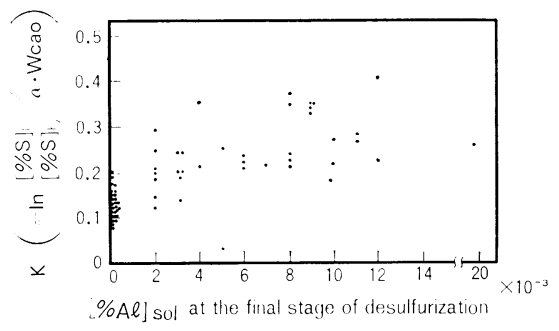

$[\mathrm{S}]_{\mathrm{I}}$ and $[\mathrm{S}]_{\mathrm{F}}$ : sulfur concentration before and after desulfurization respectively

$\alpha$ : purity of lime(-), $W_{\mathrm{CaO}}:$ comsumption of lime $(\mathrm{kg} / \mathrm{t})$

Fig. 10. Relationship between $\mathrm{K}$-value and sol[Al] after desulfurization.

す. Al 添加により脱硫速度は増大し, $\mathrm{Al}$ を添加しな い場合に較べて脱硫率も約 $30 \%$ 向上した. そして脱硫 後の到達 [ $\mathrm{S}$ ] も $\mathrm{CaO}$ 原単位 $3 \sim 5 \mathrm{~kg} / \mathrm{t}$ で $0.010 \%$ 以下, $12 \mathrm{~kg} / \mathrm{t}$ で $0.002 \%$ がえられた.

\section{$3 \cdot 2 \cdot 2 \mathrm{Al}$ の必要添加量の検討}

実操業条件下でのデータを解析して, 脱硫終了後の銑 中 $\mathrm{sol} \cdot \mathrm{Al}$ と見かけの反忘速度定数 $K$ 值との関係を求 め, Fig. 10 に示した. $K$ 值とは脱硫反応を一次反応と した場合の反応速度を比較する数值であり次式で定義さ れる。

$$
K=\ln \underset{[\mathrm{S}]_{\mathrm{F}}}{[\mathrm{S}]_{\mathrm{I}}} / \alpha \cdot W_{\mathrm{CaO}}
$$

ここで $[\mathrm{S}]_{\mathrm{I}},[\mathrm{S}]_{\mathrm{F}}$ : 脱硫処理前後の $[\mathrm{S}](\%)$

$$
\begin{aligned}
& \alpha: \mathrm{CaO} \text { の純度 }(-) \\
& W_{\mathrm{CaO}}: \mathrm{CaO} \text { の原単位 }(\mathrm{kg} / \mathrm{t})
\end{aligned}
$$

$K$ 值は脱硫後 sol. Al 濃度が $0.005 \%$ 程度までは向上 するが，それ以上 $\mathrm{A} 1$ 濃度を高めても $K$ 值は横ばいとな る. また脱硫処理中の sol. Al 損失量 ( $\Delta$ sol. Al) はほ ぼ一義的に $\mathrm{CaO}$ 原単位に比例して決まるという結果が 得られたので， $\mathrm{Al}$ 添加の効果を発揮させるのに必要な 最小 $\mathrm{Al}$ 添加量 $W_{\mathrm{Al}}$ は次式で示される.

$$
\begin{aligned}
& W_{\mathrm{Al}}=(0.005+\Delta \mathrm{sol} \cdot \mathrm{Al}) \times 10 / \eta \quad(\mathrm{kg} / \mathrm{t}) \cdots(5) \\
& \text { ここで } \eta: \mathrm{Al} \text { 添加歩留り (-) }
\end{aligned}
$$

\section{4. 考察}

\section{$4 \cdot 1 \mathrm{Al}$ 添加による $\mathrm{CaO}$ 吹き込みの脱硫反応促進機構}

$\mathrm{CaO}$ による溶銑脱硫を説明したものには，U. Pü$\mathrm{CKOFF}^{5)}$ の研究があり，溶銑中に $\mathrm{Si}$ を含まない場合は 反応生成物として $\mathrm{CaS}, \mathrm{Si}$ が存在する場合には $\mathrm{CaS}$ と calcium silicate が生成するとしている。また川合らが 石灰るつぼによる含 $\mathrm{Si}$ 銑の脱硫実験でやはり calcium silicate が生成することを報告している.ささらに FRU$\mathrm{EHAN}^{6)}$ は $\mathrm{Fe}-\mathrm{Al}$ 系の $\mathrm{CaO}$ による脱硫速度は $\mathrm{Fe}-\mathrm{Si}$ 系にくらべて大きく，この場合の反応生成物は $\mathrm{Al}_{2} \mathrm{O}_{3}$ で あるとしている. しかし著者らの研究に打いては，Al 添加の有無による反応の差異を模式的に Fig. 11 に示す ように，溶銑に $\mathrm{Al}$ を添加しないで $\mathrm{GaO}$ のみを吹き込 んだ場合には $\mathrm{Si}$ の脱硫反応により $2 \mathrm{CaO} \cdot \mathrm{SiO}_{2}, 3 \mathrm{CaO}$. $\mathrm{SiO}_{2}$ など calcium silicate が $\mathrm{CaO}$ の表層部に生成する のに対して，溶銑にあらかじめ $\mathrm{Al}$ を添加したのち $\mathrm{CaO}$ を吹き込む場合には $\mathrm{CaO}-\mathrm{Al}_{2} \mathrm{O}_{3}-\mathrm{FeO}\left(\mathrm{Fe}_{2} \mathrm{O}_{3}\right)$ 系の反応

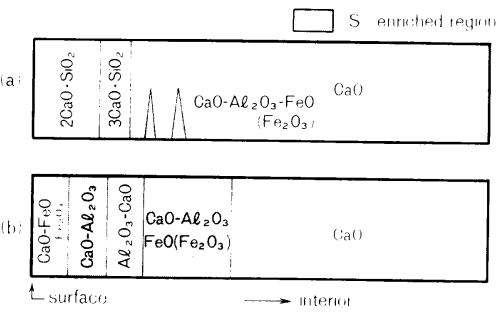

(a) no $\mathrm{Al}$ addition

(b) $\mathrm{Al}$ addition

Fig. 11. Schematic diagram of reaction layer. 


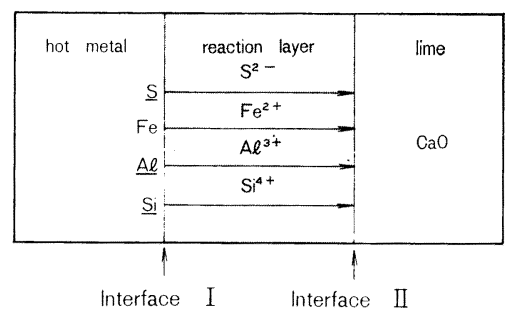

Fig. 12. Schematic model of desulfurization reactions.

層を形成する，そしてこの反応層中に S が高濃度に含ま れる. また反応層の $\mathrm{X}$ 線回折の結果, $\mathrm{CaS}$ のほかに 12 $\mathrm{CaO} \cdot 7 \mathrm{Al}_{2} \mathrm{O}_{3}, 4 \mathrm{CaO} \cdot \mathrm{Al}_{2} \mathrm{O}_{3} \cdot \mathrm{Fe}_{2} \mathrm{O}_{3}, 2 \mathrm{CaO} \cdot \mathrm{Fe}_{2} \mathrm{O}_{3} \cdot 2 \mathrm{CaO}$ $\cdot \mathrm{SiO}_{2}$ などが検出され， EPMA に上る分析結果におい ても $\mathrm{S}, \mathrm{Al}$, 少量の $\mathrm{Si}$ に加えて多量の $\mathrm{Fe}$ が検出され た.

ところで, 浸漬 $\mathrm{CaO}$ 中への溶銑中各元素の浸透は $2 \cdot 2 \cdot 2$ でのべたように, 溶銑中に S が存在することによ つてはじめて進行する. このことはカップリング現象7) を示しており，物質移動就よび反応モデルを Fig. 12 の ごとく推定した.

界面 I に拈いては (6)式で示すカッード反応が，また (6) 式に対置する反応として (7)〜 (9) 式のアノード反 応がおこり各イオンは $\mathrm{CaO}$ 内部へ移動する.

界面 I

$$
\begin{aligned}
& \text { カソード反応 } \\
& \mathrm{S}+2 e^{-} \longrightarrow \mathrm{S}^{2-} \\
& \text { アノード反応 } \\
& \mathrm{Al} \longrightarrow \mathrm{Al}^{3+}+3 e^{-} \\
& \mathrm{Si} \longrightarrow \mathrm{Si}^{4+}+4 e^{-} \\
& \mathrm{Fe} \longrightarrow \mathrm{Fe}^{2+}+2 e^{-}
\end{aligned}
$$

一方界面IIにおいては，まず(10)式の反応がおこり， 生成した $\mathrm{Ca}^{2+}$ および $\mathrm{O}^{2-}$ の各イオンは(11)〜 (13) 式 に示す反応を行らものと考えられる.

界面 II

$$
\mathrm{CaO} \longrightarrow \mathrm{Ca}^{2+}+\mathrm{O}^{2-}
$$

$\mathrm{Ca}^{2+}+\mathrm{O}^{2-}+\mathrm{S}^{2-}+\mathrm{Al}^{3+} \longrightarrow \mathrm{CaS}+\mathrm{Calcium}$

aluminate

$\mathrm{Ca}^{2+}+\mathrm{O}^{2-}+\mathrm{S}^{2-}+\mathrm{Si}^{4+}$ $\mathrm{CaS}+$ Calcium

silicate

$\mathrm{Ca}^{2+}+\mathrm{O}^{2-}+\mathrm{Fe}^{2+} \longrightarrow$ Calcium ferrite $\cdots(13)$

ここで $\mathrm{Al}$ 添加の場合には, 反応層の調査結果から推 定して，(11)式扣よび (13) 式の反応が進み, Al を添加 しない場合には(12)式および(13)式の反応が進む.

溶融酸化物の $\mathrm{S}$ 溶解能に関しては，E. T. TURKDO-
GAN $5^{8)} F . D$. RichaRdSON9) の研究があり, calcium aluminate が calcium silicate より $\mathrm{S}$ の吸收速度 やサルファイドキャパシティーの大きいことが報告され ている.そこで著者らは， $\mathrm{CaO}$ による $\mathrm{Fe}-\mathrm{C}_{\mathrm{sat}}-\mathrm{Si}-\mathrm{S}$ 系および $\mathrm{Fe}-\mathrm{C}_{\mathrm{sat}}-\mathrm{Al}-\mathrm{S}$ 系の脱硫反応生成物を代表する ものとして $2 \mathrm{CaO} \cdot \mathrm{SiO}_{2}$ 拈よび $3 \mathrm{CaO} \cdot \mathrm{Al}_{2} \mathrm{O}_{3}$ を選び浸 漬実験を行つた.

その結果, 浸漬時間 $5 \mathrm{~min}$ で $2 \mathrm{CaO} \cdot \mathrm{SiO}_{2}$ の場合は $\mathrm{Fe}$ と若干の $\mathrm{A} 1$ 以外は浸透せず，脱硫反応もごくわずか であつた。一方 $3 \mathrm{CaO} \cdot \mathrm{Al}_{2} \mathrm{O}_{3}$ の場合は, 表層の一部が 溶出し, 反応層が厚く, $\mathrm{Fe}, \mathrm{S}, \mathrm{Si}$ の移動が認められ た.さらに Photo. 3 に示した未溶解石死を含む $80 \%$ $\mathrm{CaO} \cdot 20 \% \mathrm{Al}_{2} \mathrm{O}_{3}$ 塊の浸漬実験で各元素の移動はまずー トリックスである calcium aluminate 領域で進行し, ついで $\mathrm{CaO}$ の粒子が消失して $\mathrm{CaO}-\mathrm{Al}_{2} \mathrm{O}_{3}-\mathrm{FeO}\left(\mathrm{Fe}_{2} \mathrm{O}_{3}\right)$ 相部で高濃度の $\mathrm{S}$ が検出されている.これらのことか ら, $\mathrm{CaO}$ 脱硫においては, 表層部に $\mathrm{CaO}-\mathrm{Al}_{2} \mathrm{O}_{3}-\mathrm{FeO}$ $\left(\mathrm{Fe}_{2} \mathrm{O}_{3}\right)$ の溶融スラグが生成し, $\mathrm{S}^{2-}$ イオンの通路と なつて脱硫反応を有利にしていると考えられる， $\mathrm{CaO}-$ $\mathrm{Al}_{2} \mathrm{O}_{3}$ 系で $12 \mathrm{CaO} \cdot 7 \mathrm{Al}_{2} \mathrm{O}_{3}$ 近傍が最低融点組成である が，Calcium aluminate の吹き込及実験において，より 融点の高い $3 \mathrm{CaO} \cdot \mathrm{Al}_{2} \mathrm{O}_{3}$ などにくらべて $12 \mathrm{CaO} \cdot 7 \mathrm{Al}_{2} \mathrm{O}_{3}$ の脱硫速度がやや遅いことは, 脱硫反応には $\mathrm{S}^{2-}$ の移 動を容易にする液相の通路と活量の大きい $\mathrm{CaO}$ の存在 が必要であることを示すものと考えられられる.

したがつて, $\mathrm{Al}$ 添加の場合は $\mathrm{CaO}$ の表層部に $\mathrm{S}$ の 溶解能が大きく, 低融点の $\mathrm{CaO}-\mathrm{Al}_{2} \mathrm{O}_{3}-\mathrm{FeO}\left(\mathrm{Fe}_{2} \mathrm{O}_{3}\right)$ が 生成することにより実験温度で液相化した反応層中を $\mathrm{S}^{2-}$ イオンが容易に移動して反応層と接する活量の大き い $\mathrm{CaO}$ と反応するため脱硫反忘が促進されるものと推 察される. 一方 $\mathrm{Al}$ を添加しない場合には, $\mathrm{S}$ の溶解能 に乏しい高融点の Calcium silicate が生成して $\mathrm{CaO}$ の表層部を覆うため, $\mathrm{S}^{2-}$ イオンの移動が困難となり, 反応が停滞するものと思われる。この考察は calcium aluminate 溶融粉末の溶銑への吹き込み結果が $\mathrm{Al}$ 添 加, $\mathrm{CaO}$ 吹き込及法に近い值を得たこととよく対灾し ている.

また物質移動の通路としては，各元素が粒界に偏在し ている場合があること拈よび $\mathrm{CaO}$ 粉末を約 $2000 \mathrm{~kg}$ $/ \mathrm{cm}^{2}$ の圧力でプレスして $1840^{\circ} \mathrm{G}$ で焼成した緻密な 試料よりも，ロータリーキルンで焼成した $\mathrm{CaO}$ の方が $\mathrm{Fe}$ の先行浸透が認められることから, $\mathrm{CaO}$ の結晶料 内よりは物質移動が容易である粒界やクラック，気孔な どを通じて優先的に行われるものと推察される. 


\section{$4 \cdot 2$ 脱硫反応の律速段階}

$\mathrm{Al}$ を添加しない場命の $\mathrm{CaO}$ による脱硫の律速段階 については諸説があり，F. OETERS $5^{10)}$ は溶銑中の $\mathrm{S}$ が $0.050 \%$ 以下の場命は S の 液側境膜律速， $0.050 \%$ 以上の場介には $\mathrm{CaS}$ 固相内の $\mathrm{S}$ の拡散律速とし, 川合 ら)の結果は F. OETERS らと異なり，脱硫反応生成物 含有層を通して Sの移動律速としている。溶銑に $\mathrm{Al}$ を 添加することにより脱硫速度が大きく向上するが，Fig. 7 によれば反応速度定数が硫黄の初期濃度: $[\mathrm{S}]_{\mathrm{I}}$ によ て変化することから， $300 \mathrm{~kg}$ 高周波唀導溶解炉に打け る $\mathrm{CaO}$ 以き达及尖験条件卜における反応の律速段階は 液側境膜律速とはいえず，反灾生成物含有層を通しての 移動律速と考えられる、溶銑中にS $\mathrm{S}$ を含まない場合には 反応層が生成されないのに対し， $\mathrm{S}$ を含む場合には $\mathrm{S} の$ 溶解能の大きい溶融反迌層が形成されることを前述した が，Fig. 7 に执いて $[\mathrm{S}]_{\mathrm{I}}$ により反応速度定数が異な るのは $[\mathrm{S}]_{\mathrm{I}}$ が大きいほど $\mathrm{S}^{2-}$ の移動が容易な溶融反 忘層が形成されやすいためと考えられる。

\section{$4 \cdot 3$ 必要 $\mathrm{Al}$ 濃度の検討}

Fig. 10 に示したように，Al 添加の効果を発揮させ るためには脱硫処理後の sol. [A 1$]$ 濃度を $0.005 \%$ 以上 に確保して拉く必要があるが，その理由について以トに 考察する.

炭素飽和浴鉄の脱酸半衡に関しては $2 \sim 3$ の研究11)12) があるが，ばらつきが大きく，このため炭素を含まない 溶鉄の脱酸斗衡について検湖する．Si および $\mathrm{Al}$ に関 して学振推奨値13) として次の式が示されている.

$$
\mathrm{SiO}_{2(\mathrm{~S})}=\mathrm{Si}+2 \mathrm{O} \quad \log K=-30720 / T+11.76
$$

$\mathrm{Al}_{2} \mathrm{O}_{3(\mathrm{~S})}=2 \mathrm{Al}+3 \mathrm{O} \quad \log K=-64900 / T+20.63$ ここで適用温度ト限の $1550^{\circ} \mathrm{C}$ での $\mathrm{Al}=0.005 \%$, と $\mathrm{Si}=0.50 \%$ の平衡酸素值を求めるとそれぞれ $3.5 \mathrm{ppm}$, $38 \mathrm{ppm}$ となり $\mathrm{Al}=0.005 \%$ で $\mathrm{Si}$ に優先脱酸するこ とには刘忍しない，しかし現場操業における $\mathrm{Si}$ および Al 脱酸については， 大ラグや附火物による再酸化があ り, さらに溶鉄内介在物中の $\mathrm{SiO}_{2}, \mathrm{Al}_{2} \mathrm{O}_{3}$ の活荲の変 化 ${ }^{14)}$ に伴ら脱酸能から， $\mathrm{Al}=0.005 \%$ で $\mathrm{Si}=0.50 \%$ に 優先して脱酸することになるものと考えられる.

\section{5. 結言}

溶銑脱硫における $\mathrm{CaO}$ の反応速度を向上させるた め, 溶銑に $\mathrm{Al}$ を添加し, ついで $\mathrm{CaO}$ を吹き込むこと
により脱硫するカ法について研究し以トの結論を得た.

(1) 溶銑中にあらかじめ $\mathrm{Al}$ を添加し, $\mathrm{CaO}$ の吹 き込久中 $\mathrm{Al}$ 濃度を $0.005 \%$ 以上に保持することによ り，脱硫速度を大幅に向上させることができる。

(2) Al 添加による脱硫反応促進機構は次のように 説明される。すなわち， $\mathrm{Al}$ を添加しない場合には $\mathrm{GaO}$ の表層部に高融点でかつ $\mathrm{S}$ の溶解能に乏しい calcium silicate が生成して $\mathrm{S}^{2-}$ イオンの移動を妨げるのに対 し, $\mathrm{Al}$ 添㞦の場命には $\mathrm{CaO}$ の表層部に $\mathrm{CaO}-\mathrm{Al}_{2} \mathrm{O}_{3}$ $\mathrm{FeO}\left(\mathrm{Fe}_{2} \mathrm{O}_{3}\right)$ 系の溶融スラグ層が生成し， $\mathrm{S}^{2-}$ イオンが スラグ層を"享易に移動し，活量の大きい内部の $\mathrm{CaO}$ と 反応する。

（3） Al 添加法を実操業の混銑車上吹き脱硫法に適 用した結果，脱硫速度は約 2 倍に问上し，脱硫摔も約 30\% 向上することがわかつた.

本研究をまとめるにあたり，有益な沽論をいただきま した大阪大学荻野和已教授, 東北大学德田昌則教授に感 铸いたします。

\section{文献}

$1) \quad N$. Tsuchiya, $H$. Ooi, $A$. Ejima, $K$. Sambongi: Symposium on External Desulphurization of Hot Metal, McMaster Univ. May (1975)

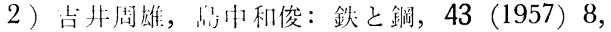
p. 807

3）川合保治，森 壳已，晋好史：鉄と銅，61 (1975) 1, p. 29

4) B. Trentini, L. Wahl, M. Allard: JISI, (1956) June, p. 124

5 ) $U$. Pückoff: Symposium on External Desulphurization of Hot Metal, McMaster Uhiv. May (1975)

6 ) R. Fruehan: Met. Trans., 9B (1978), p. 287

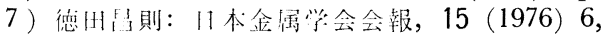
p. 379

8 ) $E . T$. Turkdogan, M. Pearce: Trans. Aime, 227 (1963), p. 940

9 )F. Richardson: Thans. AIME, 233 (1965), p. 1586, 243 (1969), p. 319

10) $F$. Oeters, $P$. Strohmenger, and $W$. Plusc HKELL: Arch. Eisenhüttenw., 44 (1973) 10, p. 727

11）萬谷志蚛，的場占雄：鉄と铜，44（1958）6, p. 643

12) 柳汱将，九山益輝：鋳物， 49 (1977) 7, p.417

13）学振製鋼 19 委員会：製銓反忍の推奨必衡檤 (1968) [日刊工業新聞社:]

14) A. Palmers, $J$. Defays, and $L$. Philippe: C. R. M No. 55 (1979) Nov., p. 15 